\title{
Strategic Management of Public Interest Organizations
}

\author{
Kees van der Pijl ${ }^{1}$ and Harry Sminia ${ }^{2,3}$
}

This paper argues that strategic management of a public interest organization not only needs to be aimed at the interests it represents, but it also has to incorporate the organization's internal workings. The functioning of a public interest organization is seen to suffer from a primary dilemma of membership and influence and a secondary dilemma of representation and control. If these dilemmas are not handled adequately, the public interest organization will suffer from a vicious circle of contradiction and conflict, eventually threatening the organization's long-term viability. A case study is elaborated to empirically underpin this proposition.

KEY WORDS: public interest organization; voluntary organization; strategic management; structuration theory; mentally handicapped people.

\section{INTRODUCTION}

What does strategic management mean for a public interest organization (PIO)? Strategy is about "purposes, directions, choices, changes, governance, organization, and performance of organizations in their industry, market and social, economic, and political contexts" (Pettigrew et al., 2002, p. 3). Mainstream strategic management theory is based on a causal relationship between competitive advantage and (financial) performance. A number of alternative approaches have been developed to describe the sources of competitive advantage, varying from ways to position a firm in an industry (Porter, 1980) to tracing the sustainable competitive advantage of the firm's resources (Barney, 1986; Wernerfelt, 1984).

${ }^{1}$ CIVIQ, The National Volunteer Center, Utrecht, The Netherlands.

${ }^{2}$ Department of Administrative and Organization Sciences, Faculty of Social Sciences, Vrije Universiteit, Amsterdam, The Netherlands.

${ }^{3}$ Correspondence should be directed to Harry Sminia, Department of Administration \& Organization Sciences, Faculty of Social Sciences, Vrije Universiteit, De Boelelaan 1081c, 1081 HV Amsterdam, The Netherlands; e-mail: h.sminia@fsw.vu.nl 
As a result, there are distinctive schools of thought that provide management with various recommendations about the appropriate strategic direction. Unfortunately these insights are biased toward the for-profit business firm.

Virtually all PIOs are nonprofit and therefore require a different approach to strategic management. A similar problem has emerged in the realm of corporate governance and nonprofit organizations (Eldenburg et al., 2001; Saidel, 1998), as much of the theory on corporate governance presumes profit as a guiding principle. The reasons for existence of PIOs, of course, are the interests these organizations promote and protect. As a consequence, strategic management of this type of organization has to be directed toward handling these interests (Berry, 1977; Boardman and Vining, 2000). However, PIOs can experience a real crisis when they are confronted with changes to the interests they are supposed to protect (Selsky, 1998). Besides, both attention to strategy and organizational structure have been identified as being essential for the viability of a PIO (Grant, 1995; Young et al., 1999). In this paper the protection and promotion of interests on their own are seen as an insufficient base for the successful strategic management of PIOs. The proposition is to supplement strategy based on the handling of interests with strategy that deals with the internal workings of the organization. It will be demonstrated that ill treatment of the internal workings of a PIO directly affects its viability, and therefore this aspect is put forward as essential for PIO strategic management.

The research on which this paper is based followed a case-study design aimed at analytical generalization as advocated by Yin (1994). This requires theoretical propositions to be put forward with which the patterns in the data can be matched. The theoretical propositions are based on research done in the realm of interest organizations in general that revealed these organizations suffer from two basic problems that are presented here in the form of two dilemmas. Next, the notion of dilemma within organization and management theory is examined, in turn leading to the identification of the mechanisms of vicious and virtuous circles that each describe specific processes of dealing with a dilemma (Hampden-Turner, 1990, 1994). The mechanism of the vicious circle is elaborated in more detail by building on structuration theory (Giddens, 1979, 1984) to be able to match this mechanism with the pattern that was observed in the actual case. The case in question is the $\mathrm{FvO}$ (Federatie van Ouderverenigingen, Federation of Parent Associations): a Dutch PIO, which protects the interests of mentally handicapped people and their parents/relatives. As it appeared the theoretically predicted pattern of the vicious circle matched the empirically based pattern of events that occurred in the $\mathrm{FvO}$ case over a period starting in the 1950s up to 2002. The data on which the case description is based are predominantly derived from internal $\mathrm{FvO}$ policy documents and a historical study of the social services for mentally handicapped people in The Netherlands (Beltman, 2001). The interpretation of the data was enhanced by the experiences gained by the first author as a consequence of his employment as policy advisor by the FvO from 1999 to 2003. 


\section{THE WORKINGS OF PUBLIC INTEREST ORGANIZATIONS}

A PIO is a complicated organization when it comes to strategic management. The traditional hierarchy that normally is associated with the concept of formal organization only partly applies to a PIO as both an organization structure in terms of management and employees can be distinguished alongside a representation structure of members, volunteers, and executive committees. Establishing purpose and direction within a PIO is normally a joint responsibility of both management and executive committees.

As a consequence of the research along the "pluralist vs. neo-corporatist paradigm" (Streeck, 1992; Streeck and Schmitter, 1985), two problems with regard to defining purpose and direction of PIOs have surfaced (Van Waarden, 1992). First, how do individuals organize themselves to become capable collective actors? Second, how do PIOs effectively represent the interests of their supporters in the public domain? Neo-corporatism saw PIOs and government essentially as a closely knit fabric, while pluralism emphasized the position of an interest organization to be better characterized as a buffer between vulnerable private citizens on the one hand and powerful government on the other.

These two questions, in turn, can be interpreted as giving rise to two dilemmas, which are considered to be typical for PIOs (Streeck and Schmitter, 1985; Van Waarden, 1992). The primary dilemma concerns the core process of this type of organization, namely, the aggregation of individual interests into collective voice. This is the dilemma between membership and influence. The secondary dilemma is derived from the primary dilemma and concerns the role of management in a PIO. This is the dilemma between representation and control.

The primary dilemma between membership and influence reflects a contradiction in logic that needs to be accommodated in the PIO. The logic of membership refers to the reasons for individuals to become supporters of a particular PIO. In turn, these reasons can follow two ordering principles. The first ordering principle is based on exchange (Berry, 1977; Grant, 1995; Van Waarden, 1992). Individuals are willing to support a PIO in exchange for a certain return or utility. The second ordering principle is based on solidarity. This refers to an awareness of unity with other individuals that share a certain identity, attribute, or social cause (Streeck and Schmitter, 1985; Van Waarden, 1992). Central to the logic of membership is the highly individual convictions and reasons to join a PIO, and consequently a pull toward heterogeneity when it comes to defining direction and purpose.

Contrasting the logic of membership is the logic of influence. This logic refers to the ordering principle of government, which predominantly is based on hierarchy (Grant, 1995; Streeck and Schmitter, 1985; Van Waarden, 1992). The promotion of interests is then characterized by formal championing, aimed at influencing legislation. These processes can be described as processes of lobbying and negotiation during which compromises have to be made between various stakeholders. As a consequence, the PIO becomes intertwined with government 
policy, especially if the negotiated outcome has to be defended in the face of the organization's supporters, or if, as part of the compromise, government expects the PIO to ask their supporters for certain sacrifices. Also the PIO often becomes involved in the implementation of government policy. There is a danger here that the PIO will be identified with government policy to a degree that they become alienated from their own supporters. On the other hand, an uncompromising or ambiguous stance will disqualify the PIO from the negotiations all together. As a consequence, this side of the dilemma involves a pull toward homogeneity.

The primary dilemma of membership and influence leads to a secondary dilemma with regard to PIO management. This is the dilemma between representation and control. It refers to the problem of how a PIO has to be organized to promote and protect the interests it stands for (Grant, 1995; Knoke, 1990; Streeck and Schmitter, 1985; Van Waarden, 1992). For both sides of the primary dilemma, there is a choice between a bottom-up and a top-down approach. The bottom-up approach puts the emphasis on heterogeneity and is based on the assumption a $\mathrm{PIO}$, above everything else, needs to acknowledge every separate individual interest of its members and to represent every single one of their concerns. For a PIO to be effective, the top-down approach emphasizes homogeneity and the need to control members to the extent they more or less prescribe what the interests are that need to be voiced and how these interests are best protected, in order to be able to negotiate and compromise with the government and other external stakeholders. Besides, size of a PIO can be expected to matter as well, as larger PIOs require more professional staff that brings an additional pull toward formal hierarchy and a top-down approach to serving members needs with it.

With regard to the primary dilemma of membership and influence and the secondary dilemma of representation and control, a PIO can position itself in various ways. As for the membership side of the primary dilemma, a PIO can embark upon activities like counseling and advice, as well as services aimed at training, education, or facilitation of specific subgroups (Valkenberg, 1995). As for the secondary dilemma, at the control side, PIO management can choose to mobilize its supporters for collective action, or at the representation end, PIO management can create opportunities for self-organization facilitating processes of spontaneous and ad hoc initiative and development by its supporters. On the other hand, at the influence side of the primary dilemma, a PIO can opt for a lobby strategy. In order to lobby successfully a PIO is required to manage its supporters, therefore this is a strategy of control. In contrast, a PIO can choose for activism and protest or the creation of external pressure through scientific research, which is more of a representation strategy. Which of these strategic options is to be considered for which cause depends on the government policy process stage and the level of unity among the supporters.

Dilemma, contradiction, and paradox have been identified as being part of organization theory as well as organizational reality (Poole and Van de Ven, 
1989; Quinn and Cameron, 1988). According to Hampden-Turner (1990, 1994), dilemmas in organizations can give rise to two different types of processes, which he referred to as vicious circles and virtuous circles. In the case of virtuous circles, contradiction leads to creative tension. The opposing logic restrains itself, resulting in a self-correcting dynamic balance (Mastenbroek, 1987; Pascale, 1990). According to Hampden-Turner (1990, 1994), a dilemma turns into a vicious circle when the opposing logic leads to diversion, breaking up the possibility of mutual influence and creative tension, eventually leading to a situation of destructive polarization, with the organization losing its capability to learn and develop. Especially PIOs, with their built-in dilemmas are prone to become entrapped in such a vicious circle, particularly when its strategic management becomes too much engrossed in the interests it protects and promotes, and its internal functioning is being neglected as a consequence.

Given these dilemmas of membership and influence, and of representation and control, the organizational structure of a PIO requires careful thought to encourage the mechanism of the virtuous circle and to discourage the mechanism of the vicious circle. Consequently, the functioning of the organization and the way the organizational structure is designed is of strategic importance to the viability of a PIO. A PIO whose design inhibits confrontation along the two dilemmas will lack the ability to learn and develop, with eventual dire consequences. If a PIO is primarily focused on influencing government and "forgets" to pay attention to its members, sooner or later this PIO will become an empty shell.

\section{THE VICIOUS CIRCLE AND VIRTUOUS CIRCLE PROCESSES EXAMINED}

In structuration theory (Giddens, 1979, 1984), contradiction is seen as inherent in the duality between agency and structure. The structural attributes of a social system shape individual agency while simultaneously the interactions produce and reproduce the social system. Furthermore, individuals are self-reflective and can decide to act against the prevailing social structure. In this case, structuration does not result in continuity of the social system and its accompanying interaction patterns, but turns into a process of change. As a consequence, contradictions are a basic part of social process, linked as they are with learning, self-reflection, and change. Giddens (1979) distinguishes between primary and secondary contradictions. In his words, a primary contradiction "can be identified as fundamentally and inextricably involved in the systems reproduction" while a secondary contradiction is "brought about through the existence of primary contradictions, and which are in some sense a result of them" (Giddens, 1979, p. 143). In the case of a PIO, the primary contradiction appears as the dilemma between membership and influence. The secondary contradiction is the dilemma between representation and control. 
Giddens' structuration theory has been put forward as very helpful in resolving issues with regard to dilemmas, contradictions, and paradoxes in the realm of management and organization theory (Poole and Van de Ven, 1989), although critics argue structure is "conflated" with agency (e.g., Archer, 1982). It is an approach that is gaining wider recognition (Whittington, 1992). Examples are the study of accounting practices (Scapens and Roberts, 1993), organization structure (Ranson et al., 1980), management (Watson, 1994; Willmott, 1987), technological change and innovation (Barley, 1986; Orlikowsky, 1992), and strategic change (Hellgren and Löwstedt 1998; Pettigrew, 1985).

Turning to structuration theory here is helpful in two ways. First, it underpins the mechanisms of virtuous circles and vicious circles (Hampden-Turner, 1990, 1994) described above. A vicious circle can be understood as a contradiction, which, in terms of structuration theory, leads to system degeneration. System degeneration is a process that eventually leads to a standstill and proliferation of the existing state of affairs, with new demands not being met as these just serve as a means to confirm the dilemma. On the other hand, a virtuous circle has a contradiction turning into a conflict that is characterized by self-reflection, learning, and change, resulting in a capability to develop and grow when new demands need to be met. Being able to develop and learn while dealing with new demands is essential for the vitality of a PIO as the interests that need protection inevitably change with the passing of time and therefore pose new demands.

Second, structuration theory allows for a better reading of the nature and content of a dilemma. In terms of structuration theory, a dilemma refers to one or more of the modalities of social structure. These modalities are meaning, power, and value. The modality of meaning refers to the process of communication and the prevailing interpretive schemes that are part of the social structure. In the case of a dilemma with regard to the modality of meaning, there are rival definitions of the situation. The modality of power refers to the process of facilitation or the differences in opportunity that are present in a social structure. A dilemma here takes on the form of a conflict of interests. Value refers to the process of sanctioning, or abiding to existing norms and values. With this modality a dilemma questions the legitimacy of certain norms and values.

Looking at the primary dilemma of membership and influence and the secondary dilemma of representation and control that have been identified as being typical for PIOs, these can be further elaborated in terms of meaning, power, and value. As has been explained above, a PIO basically has to deal simultaneously with the public domain, mostly in the form of the government, and with the private domain or the individual supporters of this organization. This is reflected in the complexity of the internal organization of a PIO, with its dual logic of organizational structure and representational structure. The government comes from a position where they have to deal with the interests of a particular group in society 
from the perspective of the general public interest while the supporters want their specific and individual interests to be catered for by the government, perhaps in spite of the public interest. The PIO is caught in the middle. From a government perspective, the supporters are only one group with a private interest with which they need to make a compromise. From the supporters' perspective, there are myriad different individual interests that all need to be addressed when they are represented to the government. This means the logic of influence tends to urge the PIO to unify its claim on the government while the logic of membership implies the PIO has to diversify into every possible claim from its members.

It is obvious that this dilemma between influence and membership puts a strain on the PIO in terms of the modality of power. Unity is strength for the PIO when it comes to dealing with the government but alienates those supporters who feel their particular interests have fallen by the wayside. This refers to the tension between public and private interest that can appear as a struggle for power between various stakeholders associated with a particular PIO. Also there are differences in the interpretative schemes that have to be dealt with. The supporters come from their own private situations and each supporter interprets a compromise between the public interest and its own interests on the basis of their particular point of view, while the government deals with the PIO on the basis of a generalized public policy. This is the tension between the private and the public domain that can amplify and intensify conflict between stakeholders. Likewise, government will act from a fairly common set of norms and values while on the other hand differences between individual supporters are very likely. This refers to the tension between collective culture and private identity, which also potentially adds to a conflict.

The secondary dilemma of representation and control suffers from a similar problem. This dilemma refers to the manner in which the PIO needs to be managed. As has been explained above, the representation end of this dilemma sees the PIO primarily as a bottom up organization. Therefore, it has to be organized in such a way that it accommodates all the different interests, interpretative schemes, and sets of norms and values present among the supporters of this organization. This means a PIO is organized from the bottom-up: featuring a multitude of interests, a heterogeneous culture, and a complex array of points of view. The control end of the dilemma emphasizes unity and with a top-down hierarchy, concentrating on a limited number of interests, with leadership backed by a single central particular interpretative scheme and set of norms and values. To Giddens (1979), the situation gets out of hand when a primary and a secondary dilemma conspire and result in a situation of system degeneration. In the case of a PIO, this will happen when the control end of the secondary dilemma concurs with the influence end of the primary dilemma, or the same happens with regard to the representation and membership ends. In both cases, systems degeneration takes on the form of the vicious circle described above. 
By adopting structuration theory to describe and understand the position of the PIO, the dilemmas of membership and influence, and representation and control have been described in more detail. A PIO is a type of organization, which by definition features a continuous struggle between opposite forces in terms of meaning, power, and value. As has been put above, this does not present a negative thing, as it is the presence of contradiction that is essential for the vitality of the PIO. Contradiction is a prerequisite for self-reflection, which in turn, leads to development and change. It is essential for a PIO to have a capacity for learning, development, and change as the content of the interests will alter over time and the PIO has to be able to meet new demands. On the other hand, the possibility of system degeneration is lying in wait and needs to be guarded for. The importance of learning and of dealing with change has been identified in the strategic management literature as well (e.g., Mintzberg, 1994).

\section{THE FvO CASE AS AN EXAMPLE OF A VICIOUS CIRCLE}

The Federation of Parent Associations (Federatie van Ouderverenigingen, $\mathrm{FvO}$ ) is a PIO, which in turn is a collaboration of a number of legally independent parent associations of mentally handicapped children in The Netherlands. These parent associations originated from grassroots initiatives in the early 1950s that were linked with particular societal or religious movements in Dutch society. The FvO was created in 1964 through collaboration between the secular Helpt Elkander, the protestant Philadelphia, and the catholic Voor Het Zorgenkind associations. In 1975, the orthodox protestant Dit Koningskind joined the FvO as well as did the WOI association (see Fig. 1). The WOI association was not a parent association as such but a federation of small local parent associations that were attached to particular institutions and foster homes. In 1976, an attempt was made to merge the original founding parent associations but only Helpt Elkander and Voor Het Zorgenkind eventually joined together creating the VOGG association. Philadelphia eventually opted against the merger under pressure of the more conservative part of their support base. In 1984 another orthodox protestant parent association of Helpende Handen joined the $\mathrm{FvO}$.

In 2002 the $\mathrm{FvO}$ was still based on collaboration between five legally independent parent associations, viz., VOGG, Philadelphia, Dit Koningskind, WOI,

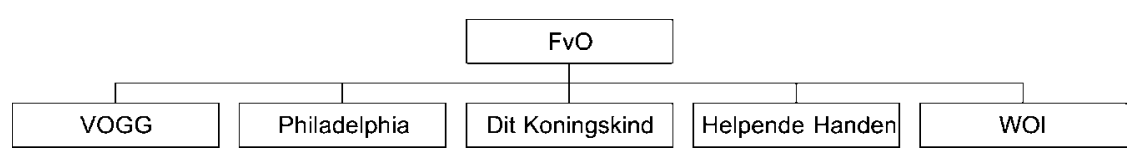

Fig. 1. FvO and member organizations. 
and Helpende Handen. On the one hand, the $\mathrm{FvO}$ had been a highly successful $\mathrm{PIO}$ in the sense they had succeeded in putting mentally handicapped people high on the national political agenda, resulting in a number of favorable government initiatives and a steady increase of public money spending on care and support. On the other hand, the $\mathrm{FvO}$ was a PIO in crisis as turnover of $\mathrm{FvO}$ management and personnel was high and membership of the five parent associations had been decimated over recent years (legally the five parent associations were the members of the $\mathrm{FvO}$ while the parents themselves had to subscribe to one of the five parent associations), while expenditures had started to exceed income. This directly threatened the immediate viability of the whole FvO organization, notwithstanding the success of handling the interests of mentally handicapped people and their families.

This PIO has fallen victim of the process of the vicious circle. The FvO case appeared to be a typical example of a PIO, which neglected the internal workings of this type of organization, especially with regard to the dilemmas that are typical for a PIO. As will be clarified below, the manner in which the FvO failed to attend to strategy in this realm resulted in an organization incapable of learning and developing. The $\mathrm{FvO}$ is standing on the brink of disaster as a consequence of the vicious circle.

The FvO like other PIOs has to deal with the two dilemmas of membership and influence and of representation and control. In this case there are roughly three groups of actors involved. There are the members of the five parent associations. These are mostly parents of mentally handicapped children. There are the parent association officials, which are usually volunteers that serve on the various boards and committees that are part of the official association's governance structure. Finally there is the professional staff that is employed by the $\mathrm{FvO}$ or one of the parent associations.

The pull of the influence side of the influence and membership dilemma surely and steadily gained significance over the years, as the Dutch national government increasingly incorporated PIOs in their policy-making process. As a result, the parent associations and the $\mathrm{FvO}$ adapted their operations to match government demands by concentrating their professional staff in one location in 1989, although the orthodox protestant Helpende Handen parent association remained separate. As a consequence, the $\mathrm{FvO}$ became a very active lobby organization on behalf of mentally handicapped people and their families. It was the professional staff, who identified most with this task, developing a need to centralize the activities of the $\mathrm{FvO}$ to fit their lobby activities.

The membership end of the membership and influence dilemma had been subject to change as well. Initially, membership of a parent association served a purpose of emancipation, solidarity, and the overcoming of shame in a society that was indifferent and sometimes hostile with regard to mental handicap. In the 1950s, most parents united themselves in the safe surroundings of the (religious) 
communities they were part of, leading to a number of different parent associations that not only dealt with the problems of mental handicaps but were also deeply rooted in the value system of those communities. Serving in the official governance structure of these associations not only required a commitment to the needs of the parents and their mentally handicapped children, but also a willingness to protect the community value system and act accordingly. As these associations served their purpose, the parents need for emancipation and solidarity was more and more being replaced by a hunger for information and knowledge about specific handicaps and syndromes. During the 1980s, some parents even founded competing associations that were devoted to particular handicaps instead of being based on religious backgrounds. An example here is the Down Syndrome Foundation.

\section{A NEW ORGANIZATIONAL DESIGN AND REGIONAL COOPERATION}

In 1993, a deliberate attempt was made to redesign the functioning of the FvO and the five member parent organizations to suit the changing needs and interests of all three of the above mentioned actor groups (see Table I for a chronology of incidents in FvO history). Especially the relationship between the parents themselves and the parents associations was seen as problematic: "Moreover, a sense is growing that support and service offered by the associations has to adapt to the new questions that the members are asking" (FvO, 1993, p. 5 translated from Dutch). This attempt can be seen as the first time in FvO history that strategic management was not only directed at providing strategy content in terms of direction and purpose for the organization as such, but also at the workings of the organization itself to be able to manage the strategic management process of continuous learning and redevelopment with regard to future direction and purpose. This new design amounted to three additions to the official FvO organizational structure. First, a number of policy working groups were established, led by FvO

Table I. Chronology of Important Incidents in FvO History

\begin{tabular}{ll}
\hline Year & \multicolumn{1}{c}{ Incident } \\
\hline 1950 & $\begin{array}{l}\text { Founding of parent associations of mentally handicapped children } \\
\text { Founding of FvO federation of parent associations by Helpt Elkander, Philadelphia, } \\
\text { and Voor Het Zorgenkind }\end{array}$ \\
1964 & $\begin{array}{l}\text { Dit Koningskind joins FvO } \\
1975\end{array}$ \\
1976 & Helpt Elkander and Voor Het Zorgenkind merge into VOGG; Philadelphia stays \\
1984 & Separate \\
1989 & Felpende Handen and WOI join FvO \\
1993 & FvO new organization design and regional cooperation \\
1996 & FvO plan for "Multicolored Cooperation" \\
2000 & FvO management conference about integration of member associations
\end{tabular}


professional staff for parent members to become involved in the lobby activities toward the government. Second, the parents' need for knowledge and information was being catered for by the introduction of information networks based on particular handicaps and syndromes, which were being maintained as a service toward the parents at central FvO level. Third, as a new Health Act required the various Dutch health organizations to organize themselves on a regional basis, the various client and patient interest organizations were forced to become involved in the Dutch health care system at a regional level as well. In the case of the FvO, this was taken up by the parent associations themselves as they were already structured in regional chapters which could be easily matched with the newly founded regional health authorities. As a consequence a number of regional federations of parent associations were established that consisted of the various regional chapters of the five parent associations. These three additions in a sense can be seen as an attempt to adapt the $\mathrm{FvO}$ organization structure to the new circumstances. Unfortunately, the manner in which this was done resulted in an organization that started to loose its ability to develop and learn.

The parent members of the five parent associations were mostly interested in the information part of the $\mathrm{FvO}$ services. The needs for solidarity and emancipation had dwindled into the background. The logic of membership, in a sense, had changed from solidarity to exchange. In terms of meaning, parents predominantly saw the $\mathrm{FvO}$ and its member associations as a service organization. To the parents the legitimacy of this PIO was very much linked with the capability of catering for specific information needs of parents with children with specific handicaps. Parents' power was very much the power of the consumer. If the service did not fulfill their needs, they simply took their business elsewhere. As a consequence, the parents embraced the information networks that were based on particular handicaps and syndromes. This was the way in which they wanted to be represented and representation had to be organized. Increasingly parents asked if they could exchange their membership of one of the parent organizations for membership of the $\mathrm{FvO}$ as the information networks were an FvO service. This, however, was legally impossible as it was only the parent organizations that according to the FvO bylaws qualified for membership.

The parent association officials remained more orientated toward the societal and religious roots of the communities from which the associations emerged. This was especially true for the parent associations of Dit Koningskind and Helpende Handen, who still were heavily rooted in their orthodox protestant background, and, to a lesser degree Philadelphia. Especially the first two associations thrived on the financial support from those religious communities as people that did not have mentally handicapped children felt obliged to support what they considered to be the less fortunate in their community. Their affluence of course boosted the power base of these two parent associations among the $\mathrm{FvO}$, as the others had been suffering from declining membership. Consequently, they also felt they had a double purpose of safeguarding the norms and values of the religious 
communities as well as helping the parents of mentally handicapped children. It was the parent association officials who became active at the regional level in the newly established regional federations. Their efforts were very much inspired by their specific value systems. Besides, the officials had the formal power in their respective associations, and also in the $\mathrm{FvO}$ as the board were made up of parent association officials.

The professional staff was divided into two subgroups. A minority, who were mostly employed by the parent associations identified more with the associations. As a consequence their orientation resembled that of the association officials. However, a majority of professional staff, mostly in the service of the FvO, had a daily job of liaising with national government on matters of policy. They saw themselves as professional lobbyists who acted on the basis of a professional ethic and had developed a knowledge base about dealing with government and national politics with regard to issues of mental handicap and health care. The policy working groups became their terrain, while their efforts of control and influence were aimed at molding the $\mathrm{FvO}$, the parent associations, and the parents to fit their lobby efforts.

These three additions to the $\mathrm{FvO}$ organization structure of policy working groups, information networks, and cooperation at regional level were designed to deal with the changing needs of the parents as well as the professional lobbyists. As these changes more or less involved pulls from opposite ends of the two PIO dilemmas, conflict and contradiction could be expected, potentially providing opportunities to learn and develop with the changing times. Conflict and contradiction did occur, but as it transpired, the three additions blocked new developments and led to stagnation instead. The main cause lay in the isolation of the parent members accompanied with a diminishing effect of the membership and representation sides of the two dilemmas, while the tension between the $\mathrm{FvO}$ professional staff and the parent association officials was starting to rise.

The parents ignored the policy working groups because their membership needs in terms of specific handicaps where not met as the policy makers and the $\mathrm{FvO}$ lobbyists were not addressing specific syndromes. Meanwhile the FvO lobby professionals stayed clear of the information networks, as their expertise with regard to national policy and gaining influence did not match the purpose of these networks. The information networks became the sole domain of the parents where they exchanged information and experiences among themselves. As a consequence, dialogue between these two actor groups lessened. The influence ends of the dilemma became attached to the level of the FvO lobbyists, while the membership part was not really catered for at central $\mathrm{FvO}$ level.

The volunteer association officials were supposed to take care of the membership side of the dilemma, but they lost touch with the parents as well. A majority of association officials, especially from an orthodox protestant origin, 
identified more with their communities than with the parents' needs. As has been said above, the association volunteers adopted the regional level of the FvO organization. This did provide them with an opportunity of covering some middle ground between the professional lobbyists at $\mathrm{FvO}$ central level and the individual parent members. Unfortunately, because of their identification with their societal and religious background, the association officials also isolated themselves from the parents and dialogue faltered here as well. Parents were not interested in officials who pursued the interests of specific communities in Dutch society, as these parents wanted information and services tailored to their needs as parents of mentally handicapped children. As a consequence, the association officials adopted a policy of control over the parents and neglected the representation end of this dilemma. From the parents' perspective, the $\mathrm{FvO}$ and member associations as a whole became a collusion of influence and control, with their needs of membership and representation dwindling to the background. One effect was that parent associations were becoming almost synonymous with the regional level, but their operations became detached from both the individual parents and central $\mathrm{FvO}$ level.

\section{A PLAN FOR “MULTICOLORED COOPERATION"}

The foundation for system degeneration had been laid. By adopting an organizational structure that effectively put the membership and representation ends out of the equation, a vicious circle had become a built-in part of the FvO organization. For a while the policy working groups, the information networks, and the regions operated flawlessly, as contradiction and conflict were more or less designed out of the equation in this regard, as each actor group could pursue their own needs uninhibited by opposition from one of the other actor groups.

As a consequence, each actor group occupied its own niche in the larger FvO movement. This was especially the case for the $\mathrm{FvO}$ lobbyists and the association officials. They both could identify with separate parts of the $\mathrm{FvO}$ organization. The lobbyists who were attached to central FvO level, acted in their professional capacity as representatives of the unified cause of the mentally handicapped and their parents and families, and concentrated on the influence end of the primary dilemma. The volunteer association officials were situated at regional level, acting as safeguards of the diversity between them. The parent associations adopted a policy of control as parent members were supposed to subscribe to the faith and worldview on which the parent association of which they happened to be a member was based. Parents could not become part of the $\mathrm{FvO}$ movement unless they become a member of one of the associations. The parent members had their information networks, which, however, were not part of the official FvO organization structure. 
The parents were losing touch with both $\mathrm{FvO}$ on the central level as well as with the parent associations, while in the meantime a rift was developing between central and regional levels as well. The need for unification in the realm of the influence at the central level, and the existing diversity and the policy of control at regional level were becoming at odds with each other. Nevertheless, in the long run, all three-actor groups would need each other for their own benefit. The professional lobbyists need people to lobby for. The parent members need lobbyists to represent their needs. The association volunteers need the parents as members and the lobbyists for their expertise.

Three years later in 1996, antagonism between the FvO lobbyists and the association officials had grown to such an extent that an attempt was made to correct the situation but unfortunately, the proposed measures only amplified the alienation of the parents more, without actually bridging the gap between central $\mathrm{FvO}$ and regional parent association level. This new plan was entitled "multicolored cooperation." Cooperation in the title addressed the need to find some common ground. Multicolored referred to the different societal and religious backgrounds of the five parent associations which still were thought of by the association officials as being an essential attribute: "the Federation exists because of strong member associations. As a consequence of the individuality and diversity of the member organizations we as a whole command a very high level of member representation" (FvO, 1996, p. 1 translated from Dutch).

One measure was to transfer the services provided for the parents from central $\mathrm{FvO}$ level back to the individual parent associations to allow the member organizations to become more visible for the parents, which in turn was considered essential for continuation of the $\mathrm{FvO}$ cooperative effort: "the existence of an area of tension between the member organizations and the Federation can not be denied. After all when more and more services are provided at the level of the Federation, the risk of the distinct member organizations being insufficiently able to make themselves known becomes more apparent. Such undermining would eventually threaten further cooperation" (FvO, 1996, p. 1 translated from Dutch). However, the parent associations, with their emphasis on the control end of the secondary dilemma were ill equipped to cater for the parents' needs, with decreasing membership numbers as a result. Another measure was to involve the professional lobbyists in the representation of parent associations at regional level. On the one hand this amplified the influence end of the primary dilemma, as it resulted in a more concerted representation of mentally handicapped people at both national and regional levels; laying the foundation for the FvO's successes in putting these people on the political agenda. On the other hand the parents more or less were sidetracked and the regional chapters of the parent associations became more attached to central $\mathrm{FvO}$ level. The chapters also transformed from being representative bodies to instruments of control. Parent initiatives were either being blocked or marginalized. As a consequence, the local chapters experienced increasing difficulties to contact new parents/supporters. 
Although the need for further cooperation between central $\mathrm{FvO}$ level and the member associations actually had been identified, it was left to the initiative of the parent associations to take measures, who in their diversity, never came to dealing with this issue properly. "When the annual member organization's plans of work are being drafted, consideration will be given as to in which area and between which member organization what form of harmonization might be possible and desirable" (FvO, 1996, p. 2 translated from Dutch). The 1996 plan resulted in some changes in the division of tasks and activities but did nothing with regard to the collusion of the influence and control ends of the dilemma. A conflict had grown among the $\mathrm{FvO}$ organization, but it was not about the built-in dilemmas. It was about how influence and control had to be organized, either based on the unified needs of the FvO lobbyists or the diversity between the member parent organizations.

\section{THE 2000 MANAGEMENT CONFERENCE}

In 2000, the issue of cooperation was on the agenda once more. It had been recognized that the $\mathrm{FvO}$ had a problem and further integration was proposed as the solution. A dedicated management conference, which was organized to tackle the situation, lead to a new zest and another three new measures. First, the intention was that an integrated plan of activities had to be formulated. Second, the paid staff of the $\mathrm{FvO}$ and the parent associations had to be brought together in one organization. Third, a unified management structure had to be implemented covering the $\mathrm{FvO}$ as well as the parent associations. These were drastic measures which, if implemented, could lead to a breaking down of the barriers between FvO central level and the member parent associations, as they would be brought together under one header. This could also bring parents back into the organization, and raised their interests of representation and membership.

As always, the proof of the pudding was in the eating, and implementation faltered largely because it was left to the old structure to make the plans work. The association officials came up with a plan of activities that did not integrate anything and amounted to nothing more but a listing of the separate activities of each of the five parent associations. This in turn led to a deep feeling of disappointment among the paid staff. Talks between association officials and the paid professionals about the design of a single $\mathrm{FvO}$ organization and the unified management structure stopped short of actually designing a single $\mathrm{FvO}$ organization and a unified management structure. The parent associations still felt strongly about their identity and were not willing to give up their autonomy. How can one have a single $\mathrm{FvO}$ organization that consists of five different associations, each organized in their own way? As a consequence, the unified management structure came to be a redesign of the FvO central offices instead of the whole $\mathrm{FvO}$ governance structure. The parents drew the short straw as the conflict still was played out at the influence and control ends of the dilemmas. 
By 2002, a significant number of paid professionals had left $\mathrm{FvO}$, not willing to continue working under these circumstances. The parents started taking their business elsewhere, leaving the associations on the brink of a membership crisis. Two new plans were drafted containing opposite solutions. One plan pushed for integration once more, while the other emphasized the autonomy of the five parent associations. The three actor groups involved became entangled in a vicious circle as the whole $\mathrm{FvO}$ organization became subject to collusion of the influence and the control ends of the primary and secondary dilemma, respectively. A conflict occurred about how influence and control had to be organized, with membership and representation being left out of the equation. System degeneration took place with the resulting vicious circle stifling this PIO and threatening its viability. The volunteer association officials saw the $\mathrm{FvO}$ as a means to foster the values of their communities. For the lobbying professionals of the FvO, the organization was an employer where they exercised their professional abilities for the particular cause of mentally handicapped people. For the parents, the $\mathrm{FvO}$ was a provider of information and services that did not perform. An attempt to appoint a new $\mathrm{FvO}$ general manager faltered in 2002 because of indecisiveness among association officials. Since then, two interim managers have come and gone, and recently a new general manager has been appointed. As things stand now, in 2004, the five member organizations emphasize their autonomy; minimizing any form of cooperation at $\mathrm{FvO}$ level, but also loosing ground with the people in the field at regional levels, while the $\mathrm{FvO}$ itself is on the brink of a financial collapse.

\section{CONCLUSIONS}

When it comes to the strategic management of PIOs, the handling of the interests it represents is an essential part of any consideration. However, the manner in which a PIO is organized is just an important issue with regard to its long-term viability. The internal operations of a PIO are more significant because of the dilemmas of membership and influence, and of representation and control that are built into this type of organization. These dilemmas need to be accommodated. Dilemma, contradiction, and paradox are not uncommon in any type of organization and their effects can either amount to a vicious circle or a virtuous circle (Hampden-Turner, 1990, 1994). In the case of a virtuous circle, the opposing logic supposedly restrains itself, leading to a self-correcting dynamic balance, while the contradiction fuels creative tension. As a consequence, a PIO has the ability to reflect and learn, and as such is consequently capable of development and change. When the opposing logic somehow is being neutralized, the possibility of mutual influence and creative tension is broken, leading to a situation of stagnation. 
The case presented here tells a story of how a particular organizational arrangement aggravates the situation, eventually leaving this PIO in a situation of crises as a consequence of the mechanism of the vicious circle. The FvO had developed into a situation where the counterforce provided by the parents' membership and representation needs had disappeared from the equation. The influence and control end of the primary and secondary dilemma became the focus of the $\mathrm{FvO}$, with a conflict developing in this realm which went out of control because the opposing logic from the membership and representation end were not there to keep it in check. In the short run, contradiction and conflict did not surface because everybody could concentrate on their own priorities, and the $\mathrm{FvO}$ on the whole seemed to be doing a good job. In the long run, however, problems arose and solutions needed to be sought that required coordination and cooperation between the three actor groups that could be distinguished, namely, the parent members, the volunteer association officials, and the professional staff at central $\mathrm{FvO}$ level. The concurrence of influence and control alienated one actor group from the $\mathrm{FvO}$ and left the other two in a situation of deadlock from which an escape seemed impossible. A solution is the reintroduction of membership and representation into the workings of the $\mathrm{FvO}$ organization. In this way the contradictions that are at the heart of the vitality of a PIO are put center stage again.

In a general sense, the mechanism of the vicious circle and system degeneration has been assessed empirically in the case of the FvO. With this case study, the dilemmas in PIOs, the danger of the vicious circle, as well as elaboration in terms of structuration theory, can be generalized against theoretical propositions in an analytical sense (Yin, 1994). A limitation, of course, with this particular case study is that it does not provide evidence with regard to the mechanism of the virtuous circle. However, as a tentative conclusion, the advice is to organize a PIO in such a way that the dilemmas inherent in this type of organization are part of all levels and units in the organization. Furthermore, addressing the internal workings of a PIO as a matter of strategy is just as important as handling the interests the organization exists for. Neglect of this issue is a potential threat to the viability of any PIO.

\section{REFERENCES}

Archer, M. (1982). Morphogenesis versus structuration: On combining structure and action. British Journal of Sociology 33(4), 455-483.

Barley, S. R. (1986). Technology as an occasion for structuring: Evidence from observations of CT scanners and the social order of radiology departments. Administrative Science Quarterly 31(1), $78-108$.

Barney, J. B. (1986). Strategic factor markets: Expectations, luck, and business strategy. Management Science 32(10), 1231-1241.

Beltman, H. (2001). Een schets van de Nederlandse verstandelijk gehandicaptenzorg 1945-2000 [A sketch of the Dutch social services for mentally handicapped people 1945-2000], Bohn Stafleu Van Loghum, Houten, The Netherlands. 
Berry, J. M. (1977). Lobbying for the People, Princeton University Press, Princeton, NJ.

Boardman, A. E., and Vining, A. R. (2000). Using service-customer matrices in strategic analysis of nonprofits. Nonprofit Management \& Leadership 10(4), 397-420.

Eldenburg, L., Hermalin, B. E., Weisbach, M. S., and Wosinka, M. (2001). Hospital governance, performance objectives and organizational form, Working Paper 8201, National Bureau of Economic Research, Cambridge, MA.

FvO. (1993). Samenwerkende oudervereniging in de jaren ' 90 [Cooperating parent associations in the 1990s], Policy document, Federatie van Ouderverenigingen, Utrecht, The Netherlands.

FvO. (1996). Veelkleurige Samenwerking [Multicolored cooperation], Policy document, Federatie van Ouderverenigingen, Utrecht, The Netherlands.

Giddens, A. (1979). Central Problems in Social Theory: Action, Structure and Contradiction in Social Analysis, Macmillan, Basingstoke.

Giddens, A. (1984). The Constitution of Society: Outline of a Theory of Structuration, Polity Press, Cambridge.

Grant, W. (1995). Pressure Groups, Politics and Democracy in Britain, 2nd edn., Harvester Wheatsheaf, New York.

Hampden-Turner, C. (1990). Charting the Corporate Mind: From Dilemma to Strategy, Basil Blackwell, Oxford.

Hampden-Turner, C. (1994). Corporate Culture: How to Generate Organizational Strength and Lasting Commercial Advantage: From Vicious to Virtuous Circles, Piatkus, London.

Hellgren, B., and Löwstedt, J. (1998). Agency and organization: A social theory approach to cognition. In: C. Eden and J. C. Spender (eds.), Managerial and Organizational Cognition, Sage, London, pp. 40-57.

Knoke, D. (1990). Organizing for Collective Action, Aldine De Gruyter, New York.

Mastenbroek, W. F. G. (1987). Conflict Management and Organization Development, Wiley, New York.

Mintzberg, H. (1994). The Rise and Fall of Strategic Planning, Prentice Hall, Englewood Cliffs, NJ.

Orlikowsky, W. J. (1992). The duality of technology: Rethinking the concept of technology in organizations. Organization Science 3(3), 398-427.

Pascale, R. (1990). Managing on the Edge: How Successful Companies Use Conflict to Stay Ahead, Penguin, London.

Pettigrew, A. M. (1985). The Awakening Giant: Continuity and Change in ICI, Basil Blackwell, Oxford.

Pettigrew, A. M., Thomas, H., and Whittington, R. (2002). Strategic management: The strengths and limitations of a field. In: A. M. Pettigrew, H. Thomas, and R. Whittington (eds.), Handbook of Strategy and Management, Sage, London, pp. 3-29.

Poole, M. S., and Van de Ven, A. H. (1989). Using paradox to build management and organization theories. Academy of Management Review 14(4), 562-578.

Porter, M. E. (1980). Competitive Strategy: Techniques for Analyzing Industries and Competitors, Free Press, New York.

Quinn, R., and Cameron, K. (eds.). (1988). Paradox and Transformation: Toward a Theory of Change in Organization and Management, HarperCollins, New York.

Ranson, S., Hinings, G., and Greenwood, R. (1980). The structuring of organizational structures. Administrative Science Quarterly 25(1), 1-17.

Saidel, J. R. (1998). Expanding the governance construct: Functions and contributions of nonprofit advisory groups. Nonprofit and Voluntary Sector Quarterly 27(4), 421-437.

Scapens, R. W., and Roberts, J. (1993). Accounting and control: A case study of resistance to accounting change. Management Accounting Research 4(1), 1-32.

Selsky, J. W. (1998). Developmental dynamics in nonprofit-sector federations. Voluntas 9(3), 283303.

Streeck, W. (1992). Social Institutions and Economic Performance: Studies of Industrial Relations in Advanced Capitalist Economies, Sage, London.

Streeck, W., and Schmitter, P. C. (eds.). (1985). Private Interest Government: Beyond Market and State, Sage, London.

Valkenberg, B. (1995). Participatie in sociale bewegingen. Een bijdrage aan de theorievorming over participatie, emancipatie en sociale bewegingen [Participation in social movements. A 
contribution to the development of theory about participation, emancipation and social movements], Jan van Arkel, Utrecht, The Netherlands.

Van Waarden, F. (1992). Organizational emergence and development of business' interests: An example from The Netherlands. Organization Studies 13(4), 521-561.

Watson, T. J. (1994). In Search of Management: Culture, Chaos and Control in Managerial Work, Routledge, London.

Wernerfelt, B. (1984). A resource-based view of the firm. Strategic Management Journal 5(2), 171180.

Whittington, R. (1992). Putting Giddens into action: Social systems and managerial agency. Journal of Management Studies 29(6), 693-712.

Willmott, H. (1987). Studying managerial work: A critique and a proposal. Journal of Management Studies 24(3), 249-270.

Yin, R. K. (1994). Case Study Research: Design and Methods, 2nd edn., Sage, Thousand Oaks, CA.

Young, D. R., Koening, B. L., Najam, A., and Fisher, J. (1999). Strategy and structure in managing global associations. Voluntas 10(4), 323-343. 